\title{
The Social Acceptance of Secondary School Students with Learning Disabilities (LD)
}

TEJA LORGER ${ }^{* 1}$, MAJdA SCHMIDT $^{2}$, AND KARIN BAKRAČEVIČ VUKMAN ${ }^{3}$

$\approx$ This paper aims to shed light on the level of social acceptance among students with learning disabilities $\left(\mathrm{LD}^{4}\right)$ in various secondary school vocational programs in comparison with their peers without disabilities. Our findings are based on an empirical study that comprised 417 students, ${ }^{5}$ of whom 85 were students with LD. Based on sociometric analyses of all participating classes, we determined that students with LD were less integrated into the classroom in comparison to their peers without LD. The results of the sociometric analysis show statistically significant differences in the sociometric position between students with LD and students without LD. While students with LD were most frequently perceived as rejected, students without LD were seen as popular or average. In addition, students with LD see themselves as less socially self-efficient compared to their peers. The results of our study mostly refer to boys, because the sample comprised 359 boys and 58 girls. We believe that pro-inclusion teachers with appropriately developed strategies for strengthening students' social skills, as well as positive attitudes and sufficient knowledge about the special needs of students can have a significant impact on the social acceptance of students with special needs in the classroom community.

Keywords: students with LD, social integration, social self-efficacy, social acceptance, sociometric status, secondary school vocational education

*Corresponding Author. III. gimnazija Maribor, Rače, Slovenia; teja.majcen@gmail.com Pedagoška fakulteta Univerza v Mariboru, Slovenia

Filozofska fakulteta Univerza v Mariboru, Slovenia

4 With the term "learning disabilities (LD)" a subgroup within the LD group is considered. This is a group of $3-5 \%$ of students with the most prominent specific learning difficulties.

5 The word "students" is used as a result of the rational notation and refers to students in secondary education. 


\section{Socialna sprejetost dijakov s primanjkljaji na posameznih področjih učenja (PPPU)}

TEJA LORGER*, MAJdA Schmidt, AND KARIN BAKRaČEviČ VuKMAN

$\propto$ V prispevku želimo osvetliti socialno sprejetost dijakov s primanjkljaji na posameznih področjih učenja (v nadaljevanju: PPPU) v različnih programih srednjega poklicnega izobraževanja $\mathrm{v}$ primerjavi z njihovimi sošolci brez posebnih potreb. Naše ugotovitve izvirajo iz empirične raziskave, v katero smo vključili 417 dijakov, od tega 85 s PPPU. Ugotavljamo, da so dijaki s PPPU slabše integrirani v oddelčne skupnosti kot njihovi sošolci brez posebnih potreb, kar smo izmerili prek sociometričnih analiz vseh sodelujočih oddelkov. Rezultati sociometrične analize namreč kažejo na statistično značilne razlike v sociometričnih položajih dijakov s PPPU in njihovih sošolcev. Medtem ko so dijaki s PPPU največkrat opredeljeni kot zavrnjeni, so dijaki brez posebnih potreb največkrat opredeljeni kot priljubljeni ali povprečni. Ob tem pa dijaki s PPPU sebi pripisujejo tudi slabšo oceno socialne samoučinkovitosti $\mathrm{v}$ primerjavi s sošolci. Rezultati naše raziskave se nanašajo predvsem na fante, saj je v raziskavi sodelovalo 359 fantov in 58 deklet. Menimo, da lahko učitelji, ki so naklonjeni inkluziji in imajo ustrezno razvite strategije za krepitev socialnih veščin dijakov, pozitivna stališča ter dovolj znanj, povezanih s posebnimi potrebami učencev, pomembno vplivajo na socialno sprejetost mladostnikov s posebnimi potrebami v oddelčni skupnosti.

Ključne besede: dijaki s PPPU, socialna integracija, socialna samoučinkovitost, socialna sprejetost, sociometrični položaj, srednje poklicno izobraževanje 


\section{Introduction}

The social integration of students with special needs $(\mathrm{SN})$ refers both to the cognitive aspects connected to efficacy and school performance as reflected by learning outcomes, and to the conative aspects related to the integration of these students into social relationships and social inclusion (Lebarič, Kobal Grum, \& Kolenc, 2006). The social integration of students with SN thus means more than merely designing individualized education programs (IEP) and implementing adaptations that have a more or less positive impact on the learning outcome; students are entitled to such adaptations after having been officially recognized as students with SN by the Slovenian National Education Institute. It means much more: it means creating an optimal environment in which students with SN can strengthen existing knowledge and acquire new knowledge, develop and strengthen social relations with peers and, in turn, build and strengthen their social competences. It means an environment in which students with $\mathrm{SN}$ is accepted, desired and equal. Peers represent an important socialization group for the student with $\mathrm{SN}$, one in which he wants to be accepted and to which he desires to belong. Exclusion from the classroom community can cause serious distress in students because the class is a formal social group in which the social interaction takes place that leads to social relationships, and that has clearly defined goals. Marentič Požarnik (1980) points out that by creating a classroom community, a class gradually turns into a group of connected individuals in which students actively engage in reaching goals and to which they develop a sense of belonging. Students gradually start to identify themselves with their peers because, during secondary socialization, peer groups become an important factor that plays a vital role in the development of students' personalities. As a relatively adaptable person, each individual is expected to be able to function in and adapt to desirable or undesirable interpersonal relationships; a certain level of social efficacy is thus expected from them. Satow and Schwarzer (2003) define the notion of social self-efficacy as an individual's faith in his own social competence even in difficult social situations. Studies that have investigated socially competent behaviour among pupils (Hubbard \& Coie, 1994; LaFreniere \& Sroufe, 1985; as cited in Zupančič, Gril, \& Kavčič, 200o) have found that social skills manifest themselves as a socially adapted, emotionally mature and pro-social behaviour that leads to positive social results in the form of popularity and acceptance in peer groups.

This study aims to investigate the social position of students with LD in a classroom community with the help of sociometric measurement, a popular and established method of researching relationships in a group (Lewis \& 
Doorlag, 1999; Rogelj, Ule, \& Hlebec, 2004). We are also interested whether the self-assessment of social self-efficacy of students with LD is similar to selfassessment of their peers.

\section{Students with SN in secondary school vocational programs}

The Placement of Children with Special Needs Act (ZUOPP-1) (2011, Article 2), which entered into force on 1 September 2013, recognizes the following as children with $\mathrm{SN}$ : children with intellectual disabilities; children with hearing and visual impairments; children with speech and language impairments; children with physical disabilities; children with long-term illnesses; children with LD; children with autistic disorders, and children with emotional and behavioural disorders who require adapted implementation of education and training programs, with additional professional support, or adapted education and training programs or special education and training programs.

After The Placement of Children with Special Needs Act (200o) came into force, the number of students with $\mathrm{SN}$ who were streamed into regular secondary school programs increased significantly. Over the previous decade, the number of such students has increased more than 15 fold (2002/2003-201 students; 2011/2012 - 3184 students) (Statistical Office of the Republic of Slovenia, 2012).

From the point of view of the students in programs included in our study, it is necessary to emphasize that between $2002 / 2003$ and 2011/2012, the number of streamed students with SN in secondary school vocational programs increased more than 31 fold (Opara et al., 2010; Statistical Office of RS, 2012). While 43 students with SN were included in secondary school vocational programs in the 2002/2003 school year, 1341 students with SN took part in them in 2011/2012. In particular, it is secondary school vocational programs into which the majority of adolescents with SN are integrated, and students with LD prevail among them (Statistical Office of RS, 2012).

It is typical of the group of students with LD that, owing to recognized or unrecognized disturbances in the functioning of the central nervous system, developmental delays occur with respect to attention, memorization, thinking, coordination, communication, social skills development and emotional growth, as well as distinct problems with regard to reading, writing, orthography and calculation (Rules on the organisation and methods of work of commissions for the placement of children with special needs and on criteria for determining the type and degree of disadvantages, impairments and 
disabilities of children with special needs, 2003). LD are internal in character; they are believed to be the consequence of a dysfunction in the central nervous system (Magajna, 2002) and have an influence on the individual's ability to interpret and/or connect information; and consequently, they impede the acquisition of learning skills (Kavkler \& Magajna, 2003). Students with LD thus do not process information in the same way as their peers, which disrupts certain ways of learning; in addition, they experience difficulties in the field of metacognition.

Grmek et al. (2009) emphasize that students with LD are precisely those students with SN who have the weakest learning-motivational and social position, which is why they require the most assistance.

\section{Sociometric position of students with SN}

Lebarič et al. (2006) point out that the social integration of pupils with $\mathrm{SN}$ is the primary objective of inclusive teaching that leads towards positive selfesteem and positive self-image and contributes to inclusion in a social group and a sense of belonging to a social group. Fostering social relationships among all parties in training and education is vital to social integration. It is necessary to strengthen ties, feelings of security, acceptance and equality and equal abilities in students with SN. This makes it possible to compare and obtain positive feedback; it also contributes to balance and stability among students with SN.

The factors necessary for successful social integration include school professionals as well as peers and fellow students. Christensen (1996) and Martin, Jorgensen and Klein (1998) point out that a negative attitude by peers towards pupils and students with SN represents a significant barrier on the way to complete social integration (as cited in McDougall, DeWit, King, Miller, \& Killip, 2004).

Studies in which inter-peer relationships were examined via a sociometric test among students with SN and their peers have mostly yielded similar results. They established that students with SN had a lower sociometric status were rejected more frequently and were less accepted that their peers (AkCamete \& Ceber, 1999; Larrivee \& Horne, 1991; Roberts \& Zubrick, 1992; Sater \& French, 1989; Smoot, 2004; Stone \& La Greca, 1990; Sahbaz, 2004; Vuran, 2005, as cited in Baydik \& Bakkaloglu, 2009; Pijl, Frostad, \& Mjaavant, 2008; Haager \& Vaughn, 1995) and struggled more to establish contacts with their school friends (Garrison-Harrell \& Kamps, 1997; Monchy, Pijl, \& Zandberg, 2004; Scheepstra et al., 1999; Soresi \& Nota, 2000; Ytterhus \& Třssebro, 1999, as cited in Pijl et al., 2008). 
From these studies, three factors have been extracted that have an important impact on the acceptance and popularity of students among their peers: They are as follows:

- Learning competences that, according to many researchers, have a significant influence on the sociometric status of individuals in the classroom. Students with lower learning competences and poorer learning results have a worse sociometric status than their school friends with average or above-average learning competences (Larrieve \& Horne, 1991; Roberts \& Zubrick, 1992; Sater \& French, 1989, as cited in Baydik et al., 2009).

- Behavioural problems proved to be an important indicator of low sociometric status. For students behaving less appropriately, a lower level of social acceptance was registered (Roberts \& Zubrick, 1992; Ummanel, 2007, as cited in Baydik et al., 2009) as was a higher level of rejection (Cantrell \& Prinz, 1985; Carlson, Lahey, \& Neeper, 1984; Coie et al., 1982; French \& Waas, 1985; Roberts \& Zubrick, 1992; Warden \& Mackinnon, 2003, as cited in Baydik et al., 2009). The studies indicate that pupils and students with LD are more frequently dealt with for having behavioural problems than their peers without LD (Cortiella, 2009, as cited in Kavkler et al., 2010).

- Social competences are competences that have a significant impact on acceptance and popularity among peers in the classroom community. Haager and Vaughn (1995) define social competences and competences that comprise social behaviour, understanding and application of social skills and social acceptance. Studies have shown that students previously rejected by their peers had less developed social competences (Sater \& French, 1989, as cited in Baydik et al., 2009), while students with well-developed social competences enjoyed better sociometric status (Coie et al., 1982; Frederickson \& Furnham, 2004; Ummanel, 2007; Warden \& Mackinnon, 2003, as cited in Baydik et al., 2009).

Sociometric analysis is often used to measure the sociometric status. Based on data obtained by a sociometric analysis of many positive and negative choices, the participants are divided into the following five groups: popular and controversial (positive), rejected and overlooked (negative) and the average (Rubin, 2000, as cited in Zupančič, Gril, \& Kavčič, 2001; Bakker, Denessen, Bosman, Krijger, \& Bouts, 2007; Vyšniauskytė-Rimkienė \& Kardelis, 2005). This division is based on a two-dimensional classification system with the following dimensions: social preferences (social popularity) and social impact (social prominence), which are defined on the basis of positive and negative choices and make possible placement into one of the sociometric groups that are defined in greater detail below (Hughes, 1988, as cited in Pečjak \& Košir, 2002). 
First, students with positive sociometric status will be defined. Popular students are those whom many peers choose as the desirable ones and only a few as the undesirable ones. They are characterized by a high social preference rate $(>1.0)$. These students are the most popular and the best accepted ones (Vyšniauskytė-Rimkienè et al., 2005). They are described as sociable, friendly, cooperative, and more successful at resolving social conflicts; they support their peers and are not hesitant to approach them; they frequently engage in discussions with others and are aggressive only in situations that frustrate them (Erwin, 1993; Putallaz \& Gottman, 1981; as cited in Durkin, 1995; Rubin, 2000, as cited in Zupančič et al., 2001). Controversial students are those that are distinctly desirable among some peers, but distinctly undesirable among others. These students exhibit a combination of the behaviour of popular (sociable) and of rejected (aggressive) students. This group of students typically has a strong social impact (> 1.0) and good leadership skills (Vyšniauskytė-Rimkienè et al., 2005). In contrast, there are the students with a negative sociometric position, who are either rejected or overlooked. It is typical of rejected students that they are not liked by many of their peers, who view them as undesirable; in addition, this group of students shows the highest level of aggressive types of behaviour (Vyšniauskytė-Rimkienè et al., 2005). They typically have a low social preference rate $(<-1.0)$. Studies have also shown that they are often antagonistic towards and critical of their peers; they often attribute hostile intentions to peers; they are more often hyperactive; they are spend significant amounts of time alone and feel more lonely than students of other groups (Asher \& Coie, 1990; Ladd \& Price, 1987; Shantz, 1986 as cited in Zupančič et al., 2001). It is typical of overlooked students that they are rarely chosen by their peers and that their social impact is low $(<-1.0)$. Vyšniauskytè-Rimkienè and Kardelis (2005) point out that, in comparison with other sociometric groups, overlooked students have lower leadership skills and very few friends; however, they are not entirely isolated in the classroom. These students are characterized by higher levels of egocentric speech; they are socially inhibited and shy, careful and withdrawn and have a negative opinion of their own social competence (Rubin, 2000, as cited in Zupančič et al., 2001). It is typical of students with an average sociometric status that they do not stand out and are neither particularly popular nor rejected. In studies that investigate behavioural correlations between sociometric status, they usually represent a comparison standard; the relatively intangible samples of behaviour of average students thus serve as a basis for comparing members of more extreme sociometric groups (Košir \& Pečjak, 2007).

The procedure defined by Coie and Dodge (1988) is used in the research. This procedure is based on standardization of the obtained positive and 
negative choices and calculation of the measures of social preference and social impact; next, students were placed in sociometric groups in terms of the criteria listed in Table 1.

Table 1. Criteria for placement of students into individual sociometric groups (Coie \& Dodge, 1988; as cited in Pečjak et al., 2002)

\begin{tabular}{lll}
\hline Sociometric group & Social preference & Social impact \\
\hline $\begin{array}{l}\text { Popular } \\
\text { (most peers choose them as desirable ones) }\end{array}$ & $>1.0$ & $\mathrm{Zp}>0 ; \mathrm{Zn}<0$ \\
$\begin{array}{l}\text { Rejected } \\
\text { (most peers do not like them, } \\
\text { peers choose them as undesirable ones) }\end{array}$ & $<-1.0$ & $\mathrm{Zp}<0 ; \mathrm{Zn}>0$ \\
$\begin{array}{l}\text { Overlooked (chosen only rarely) } \\
\begin{array}{l}\text { Controversial } \\
\text { (desirable among some peers, undesirable among others) }\end{array}\end{array}$ & $\mathrm{Zp} p<0 ; \mathrm{Zn}<\mathrm{Zn}>0$ & $>-1.0$ \\
$\begin{array}{l}\text { Average } \\
\text { (mostly accepted but do not score higher in terms of } \\
\text { acceptance) }\end{array}$ & $1.0 \geq(Z p-Z n) \geq-1.0$ & $1.0 \geq(Z p+Z n) \geq-1.0$ \\
\hline
\end{tabular}

Note:

$\mathrm{Zp}$ - Standardized positive choices,

$\mathrm{Zn}$ - standardized negative choices,

Social preference $=\mathrm{Zp}-\mathrm{Zn}$,

Social impact $=\mathrm{Zp}+\mathrm{Zn}$.

\section{Methodology}

Our study is based on a descriptive and causal-non-experimental method of empirical pedagogical research.

\section{Participants}

The empirical research is based on a non-random ad hoc sample of firstyear students from various vocational secondary school programs in northeastern Slovenia. The invitation to take part in the study was sent to secondary schools with vocational programs in Podravje ( 13 schools); 10 schools agreed to participate. The study comprised 17 classes of first-year students who are studying for a vocational secondary school degree in various fields. Only those classes in which all students were present during the sociometric test were selected.

Respondents were classified in terms of gender (male/female), age (15, $16,17,18$ years) and status (student with LD, student without $\mathrm{SN}$ ). 
The sample comprised 417 students, of whom 359 (86.1\%) were boys and $58(19.9 \%)$ were girls. The gender structure is a reflection of the fact that the majority of secondary school vocational programs included were typically maledominated (car mechanics, machinists, electricians, carpenters and builders).

The majority of students (46\%) included in the study were 15 years old, followed by 16-year-olds (39.6\%), while significantly fewer were 17 (9.4\%) or 18 years old (5\%). This age distribution was logical because the latter two groups represent students who either were repeating the class or had, for various reasons (illness, social reasons, parenthood, etc.), enrolled in the program later than their peers.

Our sample comprised $20.4 \%$ or 85 students with LD, while $79.6 \%$ or 332 did not have SN. Students with LD are officially recognized as students with SN by a Special Education Needs Guidance Order, which is a legal document stating that the students may benefit from special education, indicating the most suitable programme and institution, the type and extent of special educational support, the provision of additional human or material resources and (if needed) the reduction of class size. The document is issued by the Ministry of Education, Science and Sport of the Republic of Slovenia.

\section{Data collection procedure}

Data were collected at the end of the 2011/2012 school year in professional and vocational secondary schools in Podravje with sociometric questionnaires and social self-efficacy questionnaires. Students filled out the questionnaires during classroom meetings in agreement with the school administrations and after having obtained permission for participation in the survey from the students' parents. Surveying took place under the supervision of a professional at each school. The school counselling service at each school provided us with data on the students' status (status of a student with $\mathrm{SN}$ ) and the type of special needs.

\section{Instruments}

A sociometric test with a positive and a negative sociometric criterion was used in the study. All students in class answered the following two questions: "Whom do you get along with best in the classroom?" and "Whom do you get along with the least in the classroom?" The students answered each question by listing three school friends with whom they got along the best and the least in the classroom. Based on the data obtained with sociometric analysis via the number 
of positive and negative choices, the participants were divided into the following five groups: the popular, the rejected, the controversial, the overlooked and the average, using the procedure defined by Coie and Dodge (1988).

In addition, the students also filled out a social self-efficacy questionnaire: the Social Self-efficacy Scale by Satow and Mittag (1999). This scale measures the sense of social competence for efficient responses in various social situations, such as making friends, expressing opinion, ability to apologize for one's faults, ability to talk about one's feelings or to resolve conflicts without violence. The scale comprises eight items in which individuals express their level of agreement on a four-point scale ( $1=$ It is not true at all; $2=$ It is barely true; $3=$ It is mostly true; $4=$ It is absolutely true).

\section{Findings}

The following is a presentation of findings obtained with the sociometric analysis of 17 secondary school vocational classes of various streams.

Table 2. Result of $\chi^{2}$-test of differences in sociometric status with respect to the presence of $L D$

\begin{tabular}{|c|c|c|c|c|c|c|c|}
\hline \multicolumn{8}{|c|}{ SOCIOMETRIC STATUS } \\
\hline LD & & Popular & Rejected & Overlooked & Controversial & Average & TOTAL \\
\hline \multirow{2}{*}{ YES } & $f$ & 11 & 27 & 17 & 11 & 19 & 85 \\
\hline & $f \%$ & 12.9 & 31,8 & 20 & 12,9 & 22,4 & 100 \\
\hline \multirow{2}{*}{ NO } & $f$ & 109 & 46 & 43 & 33 & 101 & 332 \\
\hline & $f \%$ & 32.8 & 13,9 & 13 & 9,9 & 30,4 & 100 \\
\hline \multirow{2}{*}{ TOTAL } & $f$ & 120 & 73 & 60 & 44 & 120 & 417 \\
\hline & $f \%$ & 28.8 & 17,5 & 14,4 & 10,5 & 28,8 & 100 \\
\hline$x^{2}$-test & & $\begin{array}{l}\chi^{2}=24,33 \\
P=0,000\end{array}$ & & & & & \\
\hline
\end{tabular}

Based on the data obtained with a sociometric analysis of secondary school vocational students of various programs via the number of positive and negative choices, the participants were divided into the following five groups: the popular, the rejected, the controversial, the overlooked and the average.

Table 2 shows that there are statistically significant differences in sociometric status with respect to the presence of $\operatorname{LD}\left(\chi^{2}=24.337, \mathrm{P}=0.000\right)$. In students with $\mathrm{LD}$, the most common group were the rejected students $(31.8 \%)$, while students without any SN were mostly identified as popular (32.8\%) and average (30.4\%). In addition, regardless of the presence or absence of SN, 
students were most represented in the same categories as students without SN, i.e., in the group of average $(28.8 \%)$ and popular students $(28.8 \%)$.

The findings of our study are not surprising because they are in line with the results of other studies regarding the sociometric position of students with LD. Prah (2011) examined the social interaction of pupils with LD in regular primary schools in Slovenia. She established that there are statistically significant structural differences between the group of students with LD and the group of their peers considering the difficulties in social interaction (students with LD had more difficulties in social interaction). Empirical studies in the US, Switzerland, Great Britain and Germany have yielded similar results and showed that students with LD who attend regular study programs on average have a worse sociometric position than their peers (Haeberlin, Bless, Moser, \& Klaghofer, 1991). Kavkler (2005) established that peers reject 50\% of pupils with $\mathrm{LD}$, owing to problems in establishing and maintaining contacts, which no doubt poses a major problem. Stone and La Greca (1990) examined the sociometric position of pupils with LD in regular primary schools and determined that students with LD had a distinctly lower sociometric status than their peers and that they were overrepresented in the rejected and overlooked categories of students, but underrepresented in the group of popular and average students. Kavale and Forness (1996) likewise found in a meta-analysis that included 152 studies and 6353 students (the majority of whom were male $(72 \%)$ that 8 out of 10 students with LD were rejected by their peers and that students with LD had inferior social skills than their peers without them. A study from 2007 by Bakker and colleagues that analysed the sociometric position of students with both specific and general LD in regular primary schools showed that it is students with general LD who have an inferior sociometric position in regular primary schools. Wong (1991, as cited in Nowicki, 2003) also found that social problems are frequently connected with LD and that people with LD are at greater risk of social rejection. In addition, many other studies have yielded similar results and showed that primary school students who are rejected by their peers often develop social, behavioural and learning disabilities during adolescence (Bierman \& Wargo, 1995; Buhs, 2005; Coie, Lockman, Terry, \& Hyman, 1992; French \& Conrad, 2001; Parker \& Asher, 1987, as cited in Crosby, Fireman, \& Clopton, 2011).

The following is a presentation of findings the differences in the score of social self-efficacy between adolescents with LD and their peers. 
Table 3. Result of t-test of differences in the score of social self-efficacy with respect to the presence of $L D$

\begin{tabular}{|c|c|c|c|c|c|c|c|c|}
\hline & \multirow[b]{2}{*}{ LD } & \multirow[b]{2}{*}{$\mathbf{n}$} & \multirow[b]{2}{*}{$\bar{x}$} & \multirow[b]{2}{*}{$\mathbf{s}$} & \multicolumn{2}{|c|}{$\begin{array}{c}\text { Test of } \\
\text { homogeneity } \\
\text { of variances }\end{array}$} & \multicolumn{2}{|c|}{$\begin{array}{c}\text { Test of differenc- } \\
\text { es in arithmetic } \\
\text { means }\end{array}$} \\
\hline & & & & & $\mathbf{F}$ & $\mathbf{P}$ & $\mathbf{t}$ & $\mathbf{P}$ \\
\hline \multirow{2}{*}{ SOCIAL SELF-EFFICACY } & YES & 85 & 23.83 & 3.44 & \multirow{2}{*}{1.061} & \multirow{2}{*}{0.304} & \multirow{2}{*}{-3.974} & \multirow{2}{*}{0.000} \\
\hline & NO & 332 & 25.26 & 3.09 & & & & \\
\hline
\end{tabular}

The t-test result is based on a justified assumption about homogeneity of variances (Levene F-test: $\mathrm{F}=1.061, \mathrm{P}=0.304$ ). With respect to the presence of special needs, a statistically significant difference exists in the attitude of students towards their own social self-efficacy ( $\mathrm{t}$-test: $\mathrm{t}=-3.974, \mathrm{P}=0.000$ ). As can be seen in Table 3, the examined sample shows a statistically significant difference in the evaluation of self-efficacy between students with LD and their peers. Our findings can be corroborated with the findings of studies about their own perception of social self-efficacy between adolescents with LD and their peers. Adolescents with LD assessed themselves as less successful in the social area; in addition, they are more pessimistic about developing and satisfying social relations (Lackaye, Margalit, Ziv, \& Ziman, 2006).

Bandura (1997) points out that children with low social self-efficacy experience problems in interpersonal relations, are socially reserved, perceive a low level of acceptance from their peers and have low self-esteem. In an extensive longitudinal study that comprised 1361 students (of whom 55 had LD), Estell et al. (2008) found that students with LD had lower social status (social acceptance on the part of their peers, social functioning in class, underdeveloped social skills) than their peers without LD and that even inclusion does not necessarily ensure better social acceptance and better social functioning for those students with LD in a class. Our study yielded similar results. We think that problems in establishing and maintaining social skills and deficiencies in social functioning are reflected in the sociometric status of students with LD and, consequently, in their poorer social integration.

Isolation from and rejection by peers impedes access to social experiences, which has a negative impact on the sense of belonging in school and is detrimental to motivation (Asher \& Coie, 1990). A feeling of not being accepted in a classroom community develops the most strongly in adolescence when it is necessary and important for adolescents to be accepted by peers. A lack of social interaction in class during adolescence can cause a feeling of loneliness in students with LD, a sense of a lack of social skills and, in turn, can make them avoid social risks (Hendrickson et al., 1996, as cited in Baydik et al., 2009) and 
develop a poorer self-concept (Crosby, Fireman, \& Clopton, 2011).

It is therefore necessary to foster the development of social competences in response to the connection between low social self-efficacy and the sense of being unaccepted by and isolated from peers (Soresi \& Nota, 2000; Frostad \& Pijl, 2007; as cited in Pijl, Frostad, \& Mjaavant, 2011) because Pijl et al. (2011) and Crosby et al. (2011) found that it is precisely social competences that help pupils and students integrate into a group, which is why these should be developed and strengthened.

\section{Conclusion}

On the basis of the existing studies and our study, we found that in sociometric measurements, students assess their peers with LD most frequently as rejected students; simultaneously, students with LD consider themselves to be less socially efficient, which leads to the conclusion that they are less well integrated into classroom communities than their peers without SN. This happens because, in addition to LD, these students also have deficiencies in the area of social skills, which can also lead to a poorer social position. Students who are categorized as rejected often experience problems in peer-to-peer relations and are distressed because of that. The most common type of assistance to such students is social skills training (Košir, 2013). In addition to such training, which is most frequently planned and provided by a school counsellor and class teacher, students with LD who have deficiencies in the social area must also focus on the work of each teacher whose classes they attend. We believe that the teacher who assists a student with LD indirectly or directly in the development of the social skills and competences that student's needs for successful functioning at school and in society and helps him become accepted in the classroom community is the agent in the education and training system who plays a decisive role in the inclusion of all students. Qualification for implementing inclusion and a positive attitude towards pupils and students with LD are two prerequisites for quality work for professionals in Slovenian schools. The Green Paper on Teacher Training in Europe (2001) states clearly that very good teachers and their training are essential ingredients of various and numerous measures for the implementation of quality education and training (Buchberger, 2001).

In the course of their studies, teachers in Slovenia must learn how to recognize possible deficiencies, provide adaptations depending on the various special needs of pupils and students, become aware of the importance of individualized work with individuals with LD and internalize inclusive culture. Schmidt and Čagran (2011) point out that teacher training programs should 
focus more intensively and for longer on achieving teacher's self-efficacy, with possible concrete intervention strategies that promote both the learning and social development of students with all SN (Van Acker, 1993; Woolfston \& Bradey, 2009, in Schmidt \& Čagran, 2011). Galeša (1995) warns that, in order to achieve successful integration of pupils and students with all SN, in addition to knowledge and its application in practice, it is also necessary to build on the relationship and the attitude of teachers towards them. Both professional qualifications and a positive attitude on the part of the teacher are the cornerstones on which successful inclusion can be built (Avramidis, Bayliss, \& Burden, 2000; Schmidt, 1999). The TE4i project, in which teacher training and preparedness for inclusiveness were examined in 25 European countries, found that both initial training and on-going professional development were vital to the development of teacher competences and the encouragement of professional values and attitudes for work with various students in the classroom (Training Teachers for Inclusion, 2011).

A qualified teacher with an appropriate and encouraging attitude towards adolescents with LD and professional expertise can contribute significantly to the classroom climate and influence the acceptability of these students by their peers in the class. Acceptance by peers and a sense of belonging to the classroom community as well as professional treatment, assistance and adaptations from professionals can all help shape an inclusive school culture and thus strengthen the social acceptance of pupils and students LD in classroom communities.

\section{References}

Asher, S. R., \& Coie, J. D. (1990). Peer rejection in childhood. UK: Cambridge University Press. Avramidis, E., Bayliss, P., \& Burden, R. (2000). A survey into mainstream teachers' attitudes towards the incluson of children with special educational needs in the ordinary school in one local education authority. Educational Psychology, 20(2), 191-211.

Bakker, J. T. A., \& Bosman, A. M. T. (2003). Self-image and peer acceptance of Dutch students in regular and special education. Lerning Disability Quarterly, 26, 5-14.

Bakker, J. T. A., Denessen, E., Bosman, A. M. T., Krijger, E. M., \& Bouts, L. (2007). Sociometric status and self-image of children with specific and general learning disabilities in Dutch general and special education classes. Lerning Disability Quarterly, 47(30), 47-62.

Baydik, B., \& Bakkaloglu, H. (2009). Predictors Of Sociometric Status For Low Socioeconomic Status Elementary Mainstreamed Students with and without Special Needs. Educational Sciences: Theory and Practice, 9(2), 435-445.

Bela knjiga o vzgoji in izobraževanju v Republiki Sloveniji (2011). Krek, J. \& Metljak, M. (Eds.). 
Ljubljana: Ministrstvo za šolstvo in šport.

Cowden, A. P. (2010). Social Anxiety in Children with Disabilities. Journal of Instructional Psychology, 37(4), 301-305.

Crosby, K. A, Fireman, G. D., \& Clopton, J. R. (2011). Differences between non-aggressive, rejected children and popular children during peer collaboration. Child\& Family Behavior Therapy, 33, 1-19. Durkin, K. (1995). Developmental social psychology: from infancy to old age. Oxford: Blackwell. Flere, S., Klajnšek, R., Musil, B., Tavčar Krajnc, M., Kirbiš, A., \& Naterer, A. (20o8). Dejavniki šolske uspešnosti v poklicnem izobraževanju: poročilo o rezultatih raziskave. Ljubljana: Pedagoški inštitut.

Galeša, M. (1995). Specialna metodika individualizacije. Radovljica: Didakta.

Grmek Ivanuš, M., Bakračevič Vukman, K., Cencič, M., Čagran, B., Javornik Krečič, M., Schmidt, M. et al. (2009). Načrtovanje vzgojno-izobraževalnega procesa - koncepti načrtovanja kurikula. Maribor: Univerza v Mariboru, Pedagoška fakulteta.

Haager, D., \& Vaughn, S. (1995). Parent, Teacher, Peer and Self-Reports of the Social Competence of Students with Learning Disabilities. Journal of Learning Disabilities, 28(4), 205-215.

Haeberlin, U., Bless, G., Moser, U., \& Klaghofer, R.(1991). Die Integration von Lernbehinderten, Versuche, Theorien, Forschungen, Enttauschungen, Hoffnungen. Bern und Stuttgart: Verlag Paul Haupt.

Izobraževanje učiteljev za inkluzijo (2011). European Agency for Development in Secial Needs Education. Retrieved 12. 7. 2013 from http://www.european-agency.org/publications/flyers/teachereducation-for-inclusion-key-policy-messages/TE4i-policypaper-SL.pdf/view

Kavale, K. A., \& Forness, S. R. (1996). Social skills deficits and learning disabilities: A meta-analysis. Journal of Learning Disabilities, 1 29(3), 226-237.

Kavkler, M. (2005). Model sistemskega pristopa inkluzivnega šolanja. In M. Sardoč \& M. Kavkler (Eds.), Konferenca Izobraževanje otrok s posebnimi potrebami: od dobre teorija $k$ učinkoviti praksi (pp. 29-34). Ljubljana: Pedagoški inštitut.

Kavkler, M., \& Magajna, L. (2003). Primanjkljaji na posameznih področjih učenja. Retrieved 1. 11. 2012 from http://www.drustvo-bravo.si/web/index.php?option=com_phocadownload\&view=file\&id=31:.1-.-.-p-p\&Itemid=16

Kavkler, M., Magajna, L., Lipec Stopar, M., Bregar Golobič, K., Čačinovič Vogrinčič, G., \& Janželj, L. (2010). Težave dijakov pri učenju v poklicnem in strokovnem izobraževanju: Opredelitev, prepoznavanje, oblike in mreža pomoči. Ljubljana: Ministrstvo za šolstvo in šport. Retrieved 1. 4. 2012 from http://www.cpi.si/files/cpi/userfiles/Datoteke/Publikacije/Tezave_dijakov_pri_ucenju_ raziskovalno_porocilo.pdf

Košir, K., \& Pečjak, S. (2007). Dejavniki, ki se povezujejo s socialno sprejetostjo v različnih obdobjih šolanja. Psihološka obzorja, 16(3), 49-73.

Košir, K. (2013). Socialni odnosi v šoli. Maribor: Subkulturni azil Maribor. Lackaye, T., Margalit, M., Ziv, O., \& Ziman, Z. (2006). Comparisons of Self-Efficacy, Mood, Effort, and Hope Between Studentswith Learning Disabilities and Their Non-LD-Matched Peers. Learning Disabilities Research in Practice, 21(2), 111-121. 
Lebarič, N., Kobal Grum, D., \& Kolenc, J. (2006). Socialna integracija otrok s posebnimi potrebami. Radovljica: Didakta.

Lewis, R. B., \& Doorlag, D. H. (1999). Teaching special students in general education classrooms ( 5 . izdaja). New Jersey: Simon \& Schuster.

Magajna, L. (2002). Specifične učne težave-prepoznavanje, razumevanje, premagovanje. In M. Kavkler \& N. Končnik Goršič (Eds.), Specifične učne težave otrok in mladostnikov (pp. 15-29). Ljubljana: Svetovalni center za otroke, mladostnike in starše. Narodna in univerzitetna knjižnica. Marentič Požarnik, B. (1980). Dejavniki in metode uspešnega učenja. Ljubljana: DDU Univezum. McDougall, J., DeWit, D., King, G., Miller, L. T., \& Killip, S. (2004). High School-Aged Youths` Attitudes Toward Their Peers With Disabilities: the role of school and student interpersonal Factors. Internatopnal Journal of Disability, Development and Education, 51(3), 287-313.

Medveš, Z. (2007). Vzgojni koncept med vrednostno matrico in moralno samopodobo. Sodobna pedagogika, 58 (posebna izdaja), 6-29.

Medveš, Z., Kodelja, Z., Mažgon, J., Ermenc, S. K., Peček, M., Lesar, I. et. al. (2008). Prispevek poklicnega in strokovnega izobraževanja k pravičnosti in socialni vključenosti. Sodobna pedagogika, 59(5), 74-94.

Opara, B., Barle Lakota, A., Globačnik, B., Kobal Grum, D., Košir, S., Macedoni Lukšič, M. et al. (2010). Analiza vzgoje in izobraževanja otrok s posebnimi potrebami v Sloveniji. Ljubljana: Pedagoški inštitut.

Pečjak, S., \& Košir, K. (2002). Poglavja iz pedagoške psihologije. Izbrane teme. Ljubljana: Filozofska fakulteta.

Pijl, J. S., Frostad, P., \& Flem, A. (2008). The social position of pupils with special needs in regular schools. Scandinavian Journal of Educational Research, 52(4), 387-405.

Pijl, J. S., Frostad, P., \& Mjaavant, P. E. (2011). Segregation in the classroom: What does it take to be accepted as a friend?. Social Psychology of Education, 14(1), 41-55.

Prah, A. (2011). Socialne spretnosti učencev s primanjkljaji na posameznih področjih učenja vosnovni šoli. Magistrsko delo. Ljubljana: Univerza v Ljubljani, Pedagoška fakulteta.

Pravilnik o organizaciji in načinu dela komisij za usmerjanje otrok s posebnimi potrebami ter o kriterijih za opredelitev vrste in stopnje primanjkljajev, ovir oziroma motenj otrok s posebnimi potrebami. Uradni list RS, 54/2003.

Rogelj, T., Ule, M., \& Hlebec, V. (2004). Socialna opora med dijaki glede na njihov individualni položaj v strukturi popolnega omrežja v razredu. Družboslovne razprave, 20(45), 13-32.

Satow, L., \& Schwarzer, R. (2003).Entwicklung schulischer und sozialer Selbstwirksamkeitserwartung: eine Analyse individueller Wachstumskurven. Psychologie in Erziehung und Unterricht, 50(2), 168-181.

Satow, L., \& Mittag,W. (1999). Lestvica socialne samoučinkovitosti. Retrieved 10. 10. 2012 from na: http://www.erzwiss.uni-halle.de/gliederung/paed/ppsych/berichto3.pdf Schmidt, M. (1999). Učenici s teškoćama u učenju i njihova socijalna integracija. Hrvatska revija za rehabilitacijska istraživanja, 35(1), 1-9. 
Schmidt, M. (2001). Socialna integracija otrok s posebnimi potrebami v osnovno šolo. Miklavž na Dravskem polju: Univerza v Mariboru, Pedagoška fakulteta.

Schmidt, M., \& Čagran, B. (2011). Stališča slovenskih učiteljev o vplivu integracije/inkluzije na učence z različnimi vrstami posebnih potreb v osnovni šoli. Šolsko polje, 22(1-2), 55-72.

Statistični urad RS. Retrieved 20.11.2012 from http://www.stat.si/tema_demografsko_izobrazevanje. asp

Stone, W. L., \& La Greca, A. (1990). The Social Status of Children with Learning Disabilities: A Reexamination. Journal of Learning Disabilities, 23(1), 32-37.

Tancig, S. (s.d.). Metakognitivni programi za otroke s specifičnimi učnimi težavami.

Retrieved 31. 10. 2012 from http://www.drustvo-bravo.si/web/index.php?option=com_ phocadownload\&view $=$ file $\&$ id $=42: .-$ p-p $\&$ Itemid $=16$

Vončina, V., Pevec Grm, S., Silvar, B., Mali, D., Krajnc, T., Šibanc, M., Pušnik, M., \& Jeznik, K. (2006). Prvo poročilo o poteku poskusnega izvajanja izobraževalnega programa Avtoserviser. Ljubljana: Center Republike Slovenije za poklicno izobraževanje.

Vyšniauskytė-Rimkienė, J., \& Kardelis, K. (2005). Peer reputation of adolescents: sociometric status differences. Medicina (Kaunas), 41(6), 522-527. Retrieved 10.2.2014 from http://medicina.kmu. lt/0506/0506-11e.pdf

Zakon o usmerjanju otrok s posebnimi potrebami (ZUOPP-1). Uradni list RS, 58/2011. Zakon o usmerjanju otrok s posebnimi potrebami (ZUOPP). Uradni list RS, 54/200o. Zupančič, M., Gril, A., \& Kavčič, T. (200o). Predstavitev prve poskusne oblike ocenjevalne lestvice socialne prilagojenosti predšolskih otrok (OLSP) ter njene konstruktne veljavnosti. Psihološka obzorja, 9(3), 45-66.

Zupančič, M., Gril, A., \& Kavčič, T. (2001). Socialno vedenje in sociometrični položaj predšolskih otrok v vrtcu. Psihološka obzorja, 1o(2). 67-88. 


\section{Biographical note}

TEJA LORGER is a professor of pedagogy and sociology and a Doctor of Education. She works at III. Gymnasium Maribor where she teaches pedagogy. Her research interests include education of students with special needs.

MAJDA SCHMidT, Dr. is a full professor for special pedagogy/education at the Faculty of Education and Faculty of Arts, University of Maribor. Her research interests include education of children/youth with special needs both in inclusive classes and special classes. Her research studies are also focused on quality of life of families who have children with intellectual disabilities and other developmental disabilities.

KARIN BAKRAČEviČ VuKMan, Dr. is full professor of psychology at the Faculty of Arts, University of Maribor. Her research interests include cognitive and socio-emotional development in adolescence and adulthood. Her research is also focused on metacognition and self-regulation. 